\title{
Pemanfaatan Tumbuhan Melati Air (Echinodorus Palaefolius) dengan Sistem Constructed Wetlands untuk Pengolahan Grey Water
}

\author{
Monik Kasman*, Peppy Herawati, Niken Aryani \\ ${ }^{1}$ Program Studi Teknik Lingkungan, Fakultas Teknik, Universitas Batanghari, Jl. Slamet Riyadi, Broni, Jambi \\ *e-mail: emka_engineer@yahoo.com
}

\begin{abstract}
ABSTRAK
Grey water secara kuantitas dan karakteristik berpotensi menjadi sumber air baku alternatif, sehingga perlu dilakukan pengolahan. Metoda pengolahan grey water yang tepat diimplementasikan di Indonesia adalah constructed wetlands karena keragaman vegetasi, kesederhanaan konstruksi, fleksibel, mudah dan murah dalam pengoperasian dan pemeliharaan serta bernilai estetika. Vegetasi pereduksi pencemar dalam grey water yang digunakan pada penelitian ini adalah melati air karena mudah tumbuh, tidak memerlukan perawatan yang khusus, dan dari beberapa penelitian terbukti efektif dalam menurunkan BOD dan COD. Penelitian ini bertujuan untuk mengamati pengaruh waktu detensi dan kondisi sistem constructed wetlands dalam penurunan pencemar BOD dan TSS pada grey water oleh tumbuhan melati air. Waktu detensi grey water dalam reaktor constructed wetlands, meliputi 3 hari, 4 hari, 5 hari, 6 hari dan 7 hari. Kondisi reaktor constructed wetlands meliputi reaktor kontrol tanpa melati air (CW 1); reaktor dengan melati air berbunga (CW 2); reaktor dengan melati air berdaun kurang dari $(<) 20$ helai daun (CW 3) dan reaktor dengan melati air berdaun lebih dari ( $>$ )20 helai daun (CW 4). Hasil dari penelitian menunjukkan bahwa waktu detensi dan kondisi reaktor sangat berpengaruh terhadap penurunan BOD dan TSS. Konsentrasi efluen BOD dan TSS menurun dengan bertambahnya waktu detensi. Adapun berdasarkan kondisi reaktor constructed wetlands, disimpulkan makin banyak jumlah daun maka makin rendah efluen BOD dan TSS. Konsentrasi BOD dan TSS secara berurut berkisar $(1,6-3,22) \mathrm{mg} / \mathrm{L})$ dan $(0,003-0,147) \mathrm{mg} / \mathrm{L}$.
\end{abstract}

Kata kunci : Constructed wetlands; Echinodorus palaefolius; Grey water; BOD;TSS

\section{ABSTRACT}

Grey water, according to its quantity and characteristics, is potential to be source of raw water. To address this, a common approriate method has been implemented in Indonesia, is constructed wetlands system. This is due to vegetation diversity, simple construction, flexible, easy and low cost in operation and maintenance, as well as high estetics. This research is focused on observing the effects of detention time and system of constructed wetlands reactors using Echinodorus palaefolius vegetation to reduce biological oxygen demand (BOD) and Total suspended solid (TSS). The detention time varied by 3 days, 4 days, 5 days, 6 days and 7 days. The system of constructed wetlands reactors varied by blank reactor, as a control without vegetation (CW 1); reactor with few flowers (CW 2); reactor with vegetation having leaves less than $(<) 20$ (CW 3) and reactor with vegetation having leaves more than (>)20 (CW 4). The results showed that the detention time and the system of constructed wetlands reactors influences in reducing BOD and TSS. Concentration of BOD and TSS efluen decreases as the detention time increase. Besides, these concentrations decrease, as the amount of leaves increase. The concentration of BOD and TSS ranges $(1,6-3,22) \mathrm{mg} / \mathrm{L})$ and $(0,003-0,147) \mathrm{mg} / \mathrm{L}$.

Keywords : Constructed wetlands; Echinodorus palaefolius; Grey water; BOD, TSS

\section{Pendahuluan}

Grey water merupakan sumber utama limbah cair domestik, berasal dari aktivitas non kakus kamar mandi, dapur, halaman, dan buangan selain tinja (black water) (Eriksson, E., Auffarth, K., Henze, M., \& Ledin, A, 2002). Kuantitas grey water yang didominasi oleh limbah domestik pemukiman dan fasilitas umum berkisar $60 \%$ dari limbah cair domestik perkotaan, dimana $87 \%$ limbah cair perkotaan berasal dari limbah cair domestik (Kasman, M., Kalsum, S.U., Aditia, A.S., 2012b). Grey water mengandung sabun, minyak lemak, deterjen dan mikroorganisme. Grey water memiliki nilai $\mathrm{pH}$ berkisar pada $5-10$. Nilai $\mathrm{pH}$ grey water dipengaruhi oleh kebasaan air dan produk kimia yang digunakan. Konsentrasi chemical oxygen demand (COD) berkisar pada $(13$ - 8000) $\mathrm{mg} / \mathrm{L}$, biological oxygen demand (BOD) berkisar $(5-1460) \mathrm{mg} / \mathrm{L}$ ( Eriksson, E., Auffarth, K., Henze, M., \& Ledin, A., 2002). Komposisi limbah cair domestik secara umum adalah lemak $(33 \%)$, protein $(25 \%)$, selulosa $(8 \%)$, pati $(8 \%)$, lignin $(6 \%)$, abu $(20 \%)$ dan nilai BOD berkisar antara 275 - 3000 ppm (Flint dalam Kasman, M., Kalsum, S.U., Aditia, A.S., 2012b). Tingginya kuantitas dan kandungan polutan grey water berpotensi mencemari badan air penerima terutama sungai, dimana $60 \%$ - $70 \%$ pencemar air sungai berasal dari limbah domestik (Ismuyanto, 2010 dalam Suswati, A.C.S.P., 
Wibisono, G., 2013). Dampak dari pencemaran tersebut akan membahayakan dan menurunkan kualitas badan air penerima hingga menurunkan kualitas kesehatan masyarakat yang mengonsumsi air.

Upaya pengolahan grey water telah giat dilakukan. Teknologi dan metoda pengolahan yang telah diteliti dan diimplementasikan antara lain metoda adsorpsi, aerasi atau pemberian udara, flokulasi, koagulasi, sedimentasi, aerated baffled reactor dan fitoremediasiconstructed wetlands (Kasman, M., Ibrahim, S., Salmariza, 2012a; Kasman, M., Kalsum, S.U., Aditia, A.S., 2012b; Wirawan, W. A., Wirosoedarmo, R., Susanawati, L. D., 2013; Kivaisi, 2001; Vymazal, J., 2002). Pengolahan grey water dengan constructed wetlands memanfaatkan tumbuh-tumbuhan untuk mereduksi pencemar dan kontaminan (Vymazal, J., 2002, 2010). Mekanisme pengolahan grey water pada constructed wetlands mengacu pada kemampuan tumbuhan menguraikan dan mereduksi pencemar. Secara umum konsep penguraian terdiri atas fitoekstraksi, fitovolatilisasi, fitodegradasi, fitostabilisasi, rhizofiltrasi dan intereaksi dengan mikroorganisme pengurai polutan (Vymazal, J., 2008b). Pengolahan dengan sistem constructed wetland sangat tepat mengingat karakteristik air limbah grey water dengan beban organik relatif kecil, unsur nitrogen dan fosfat tinggi. Unsur nitrogen dan fosfat pada air limbah ini merupakan pupuk alami bagi tumbuhan sehingga sistem pengolahan dapat dilaksanakan dengan teknologi sederhana, praktis, mudah dan murah dalam pemeliharannya (Suswati, A.C.S.P., Wibisono, G., 2013; Suprihatin, 2014; Vymazal, J., 2008).

Constructed wetlands sangat tepat diimplementasikan di Indonesia karena keragaman vegetasi di Indonesia, kesederhanaan konstruksi, fleksibel dan pemilihan lokasi, mudah dan murah dalam pengoperasian dan pemeliharaan dan mempunyai nilai estetika (Kadlec dan Knight, 1996 dalam Suswati, A.C.S.P., Wibisono, G., 2013). Constructed wetlands dapat diimplementasikan secara insitu dan eksitu terutama penyaluran limbah desentralisasi untuk mengurangi senyawa organik dan anorganik di limbah cair dan padat. Tapi metoda constructed wetlands memerlukan waktu detensi yang cukup lama (Vymazal, J., 2010). Beberapa penelitian menyimpulkan bahwa constructed wetlands dapat menurunkan pencemar organik dan anorganik dengan menggunakan tanaman enceng gondok, kapas, bintang air, bambu air dan melati air (Prayitno, 2013).

Tumbuhan melati air (Echinodorus palaefolius) merupakan tumbuhan yang akarnya terletak pada dasar perairan dan reproduksinya secara fleksibel (Lectonen, 2009 dalam Prayitno, 2013).Tumbuhan ini dapat menurunkan kadar nutrien (eutrofikasi) pada perairan (Brouwer, 2002 dalam Prayitno, 2013). Tumbuhan melati air ini mudah tumbuh dan tidak memerlukan perawatan yang khusus. Melati air, dari beberapa penelitian efektif dalam menurunkan BOD dan COD (Prayitno, 2013). Penelitian ini bertujuan untuk mengamati penurunan pencemar BOD dan TSS pada grey water oleh tumbuhan melati air pada sistem constructed wetlands.

\section{Metode Penelitian}

Penelitian dilakukan dengan mengamati pengaruh variabel bebas terhadap variabel terikat. Variabel bebas meliputi waktu detensi dan kondisi tanaman, sedangkan variabel terikat meliputi konsentrasi akhir grey water olahan (outlet). Konsentrasi akhir outlet terdiri atas parameter pengolahan air limbah domestik mengacu pada Permen LH No. 5 tahun 2014 tentang baku mutu limbah domestik. Konsentrasi awal dan akhir dari grey water dibandingkan dan dianalisis secara deskriptif. Eksperimen dilakukan dengan mengabaikan $\mathrm{pH}$ dan suhu lingkungan di luar sistem.

\subsection{Alat dan Bahan}

Reaktor constructed wetlands terdiri atas 4 buah kontainer plastik transparan, berdiameter $25 \mathrm{~cm}$ yang dilengkapi dengan katup (valve) outlet sebagai tempat tumbuh melati air. Bak penampung sebagai tempat homogenisasi grey water. Pipa PVC dan botol sampel air olahan. Sampel Grey water diambil dari limbah cair sisa cuci piring, sisa aktivitas kamar mandi dan buangan dari saluran buangan Universitas Batanghari. Tanaman yang digunakan adalah tanaman melati air (Echinodorus palaefolius) sebagai pereduksi parameter pencemar Zeolit dan tanah humus sebagai media tumbuh tanaman melati air. Waktu detensi sangat dipengaruhi oleh permeabilitas dan konduktivitas hidrolis media. Waktu detensi mempengaruhi efisiensi dan efektifitas pengolahan karena menentukan lamanya kontak antara mikroorganisme dengan air limbah, serta oksigen yang dikeluarkan oleh akar tanaman. Susunan reaktor constructed wetlands dapat dilihat di gambar 1 .

\subsection{Eksperimen}

Eksperimen dilakukan dengan memvariasikan variabel bebas yaitu waktu detensi dan kondisi reaktor constructed wetlands. Waktu detensi grey water dalam reaktor constructed wetlands, meliputi 3 hari, 4 hari, 5 hari, 6 hari dan 7 hari. Kondisi reaktor tanaman terdiri dari 4 kondisi, reaktor kontrol tanpa melati air (CW 1); reaktor dengan melati air berbunga ( $\mathrm{CW} 2)$; reaktor dengan melati air berdaun kurang dari $(<) 20$ helai daun (CW 3) dan reaktor dengan melati air berdaun lebih dari (>)20 helai daun (CW 4). Pengamatan dilakukan untuk melihat pengaruh variabel bebas terhadap variabel terikat yaitu BOD (Biochemical Oxygen Demand) dan TSS (Total Suspended Solid) sebagai parameter pencemar yang terkandung dalam greywater. Sampel adalah grey water diambil dari saluran buangan kampus Universitas Batanghari. 


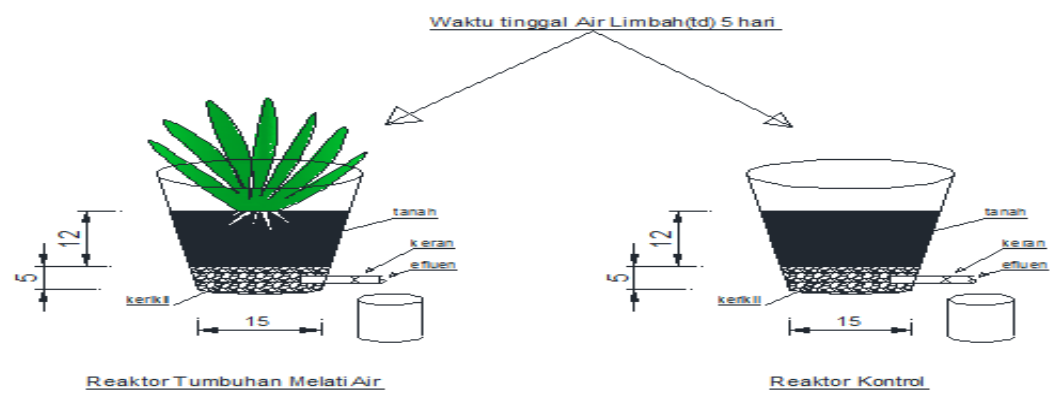

Gambar 1. Reaktor constructed wetlands

Sampel grey water diambil dan dimasukkan dalam bak penampung limbah. Sampel di bak penampung limbah dialirkan secara gravitasi kedalam bak reaktor dengan menggunakan pipa. Debit dan kecepatan aliran diatur berdasarkan waktu detensi dengan mengatur katup/ valve (kran inlet). Lama pengaliran limbah berdasarkan waktu detensi. Sampel uji dikumpulkan dari inlet (grey water sebelum diolah) dan outlet reaktor (grey water setelah diolah). Total sampel yang dikumpulkan 20 sampel dari outlet reaktor dan 1 dari inlet (bak penampung limbah). Pengujian sampel mengacu pada SNI 06-2503-1991 (BOD) dan SNI.06-6989.3-2004 (TSS).

\section{Hasil dan Pembahasan}

Sampel grey water diambil dari saluran pembuangan primer kampus Universitas Batanghari. Grey water bersumber dari aktivitas kamar mandi kampus, kantin, dan dapur. Pengambilan sampel menggunakan metoda grab sampling pada titik atau outlet pembuangan air limbah Universitas Batanghari. Pengambilan sampel dilakukan selama tiga hari berturut-turut, kemudian dimasukkan dalam bak penampung awal (inlet reaktor). Sampel dihomogenkan dengan diaduk secara manual sebelum masuk ke reaktor CW. Secara visual, sampel grey water berwarna bening, berbau tapi tidak menyengat, dan terdapat partikel-partikel diskret yang dapat mengendap dengan sendirinya. Konsentrasi parameter dapat dilihat pada tabel 1 .

Sampel grey water bersifat netral, yang diindikasikan dengan $\mathrm{pH}$ berkisar 7.3. Konsentrasi TSS dan BOD berada jauh di bawah baku mutu (Permen LH no.5 tahun 2014). Rendahnya konsentrasi kandungan pencemar grey water dikarenakan pengambilan sampel dilakukan pada saat libur kuliah, sehingga tingkat aktivitas pemakaian air rendah.
Tabel 1. Konsentrasi parameter grey water Universitas Batanghari

\begin{tabular}{lcc}
\hline \multicolumn{1}{c}{ Parameter } & Konsentrasi & Baku Mutu* \\
\hline $\mathrm{pH}$ & 7.3 & $6-9$ \\
$\mathrm{TSS}(\mathrm{mg} / \mathrm{L})$ & 0.126 & 100 \\
BOD $(\mathrm{mg} / \mathrm{L})$ & 5.64 & 100 \\
Fosfat $(\mathrm{mg} / \mathrm{L})$ & 0.127 & - \\
\hline \multicolumn{2}{c}{ *Permen LH. 5 tahun 2014 } &
\end{tabular}

\subsection{Pengaruh Pengaruh Waktu Detensi dan Kondisi Reaktor Constructed Wetlands Terhadap Parameter BOD}

Beberapa penelitian menunjukkan bahwa waktu detensi atau waktu tinggal, media dan jenis tanaman, serta kondisi lingkungan reaktor constructed wetlands sangat mempengaruhi kinerja constructed wetlands dalam penurunan parameter pencemar air limbah. Pengaruh kondisi reaktor constructed wetlands dan waktu detensi terhadap penurunan parameter BOD dan TSS dapat dilihat pada tabel 2 dan tabel 3 .

Data hasil penelitian (Tabel 2) memperlihatkan bahwa konsentrasi BOD grey water setelah diolah menurun. Penambahan waktu detensi mempengaruhi penurunan BOD efluen, dimana konsentrasi BOD terendah untuk semua kondisi reaktor constructed wetlands terjadi pada waktu detensi 7 hari (gambar 2 dan gambar 3). Konsentrasi BOD influen dan efluen berada di bawah baku mutu Permen LH no.5 tahun 2014. Bak kontrol, tanpa melati air, mempunyai konsentrasi BOD efluen lebih tinggi dibandingkan bak CW 1, CW 2 dan CW 3 dengan melati air.

Aktivitas mikroorganisme dan tanaman melalui proses oksidasi oleh bakteri aerob yang tumbuh di sekitar rhizosphere tanaman dan bakteri heterotrof dalam air limbah berperan dalam penurunan konsentrasi BOD. BOD dapat disisihkan melalui proses kimia dan biologis yang kompleks antara media material tanah dan batuan, tanaman dan mikroorganisme. Tanaman mendapatkan bahan organik sebagai nutrisi 
melalui proses dekomposisi bahan organik oleh jaringan akar tanaman. Bahan organik merupakan nutrisi dalam bentuk karbon, nitrogen dan energi.

Aktivitas mikroorganisme dan tanaman dalam penyediaan oksigen terjadi melalui proses fotosintesis. Akar tumbuhan akuatik di bawah permukaan air mengeluarkan oksigen dan membentuk zona rizosfer yang kaya oksigen. Oksigen dialirkan ke akar melalui batang secara difusi pada pori-pori daun. Pelepasan oksigen oleh akar tanaman air menyebabkan air dan tanah disekitar rambut akar memiliki oksigen terlarut yang lebih tinggi dibandingkan dengan air dan tanah yang tidak ditumbuhi tanaman air, sehingga memungkinkan organisme pengurai seperti bakteri aerob dapat hidup dalam lingkungan lahan basah yang berkondisi anaerob (Suswati, A.C.S.P., Wibisono, G., 2013; Prayitno, 2013; Fachrurozi dkk., 2010 dalam Wirawan, W. A., Wirosoedarmo, R., Susanawati, L. D., 2013)

Tabel 2. Perubahan Konsentrasi BOD dan TSS Grey Water di Reaktor Constructed Wetlands

\begin{tabular}{|c|c|c|c|c|c|}
\hline \multirow{2}{*}{$\begin{array}{c}\text { Reaktor } \\
\text { CW }\end{array}$} & \multicolumn{5}{|c|}{ Waktu detensi } \\
\hline & 3 Hari & 4 Hari & 5 Hari & 6 Hari & 7 Hari \\
\hline \multicolumn{6}{|c|}{ BOD } \\
\hline Inlet & 0.126 & 0.126 & 0.126 & 0.126 & 0.126 \\
\hline Kontrol & 0.085 & 0.079 & 0.02 & 0.031 & 0.036 \\
\hline CW 1 & 0.147 & 0.067 & 0.07 & 0.039 & 0.014 \\
\hline CW 2 & 0.037 & 0.06 & 0.03 & 0.035 & 0.013 \\
\hline CW 3 & 0.1 & 0.081 & 0.016 & 0.015 & 0.003 \\
\hline \multicolumn{6}{|c|}{ TSS } \\
\hline Inlet & 5.64 & 5.64 & 5.64 & 5.64 & 5.64 \\
\hline Kontrol & 3.22 & 2.42 & 1.21 & 1.61 & 2.01 \\
\hline CW 1 & 2.42 & 3.22 & 2.42 & 1.61 & 1.21 \\
\hline CW 2 & 3.22 & 2.42 & 2.02 & 1.21 & 1.21 \\
\hline CW 3 & 2.82 & 2.42 & 2.42 & 2.82 & 1.6 \\
\hline
\end{tabular}

Tabel 3. Persentase reduksi BOD dan TSS di Reaktor Constructed Wetlands

\begin{tabular}{lccccc}
\hline \multirow{2}{*}{$\begin{array}{c}\text { Reaktor } \\
\text { CW }\end{array}$} & 3 Hari & 4 Hari & 5 Hari & 6 Hari & 7 Hari \\
\cline { 2 - 6 } BOD \\
\hline Kontrol & $43 \%$ & $57 \%$ & $79 \%$ & $71 \%$ & $64 \%$ \\
CW 1 & $57 \%$ & $43 \%$ & $57 \%$ & $71 \%$ & $79 \%$ \\
CW 2 & $43 \%$ & $57 \%$ & $64 \%$ & $79 \%$ & $79 \%$ \\
CW 3 & $50 \%$ & $57 \%$ & $57 \%$ & $50 \%$ & $72 \%$ \\
\hline \multicolumn{6}{c}{ TSS } \\
\hline Kontrol & $33 \%$ & $37 \%$ & $84 \%$ & $75 \%$ & $71 \%$ \\
CW 1 & $0 \%$ & $47 \%$ & $44 \%$ & $69 \%$ & $89 \%$ \\
CW 2 & $71 \%$ & $52 \%$ & $76 \%$ & $72 \%$ & $90 \%$ \\
CW 3 & $21 \%$ & $36 \%$ & $87 \%$ & $88 \%$ & $98 \%$ \\
\hline
\end{tabular}




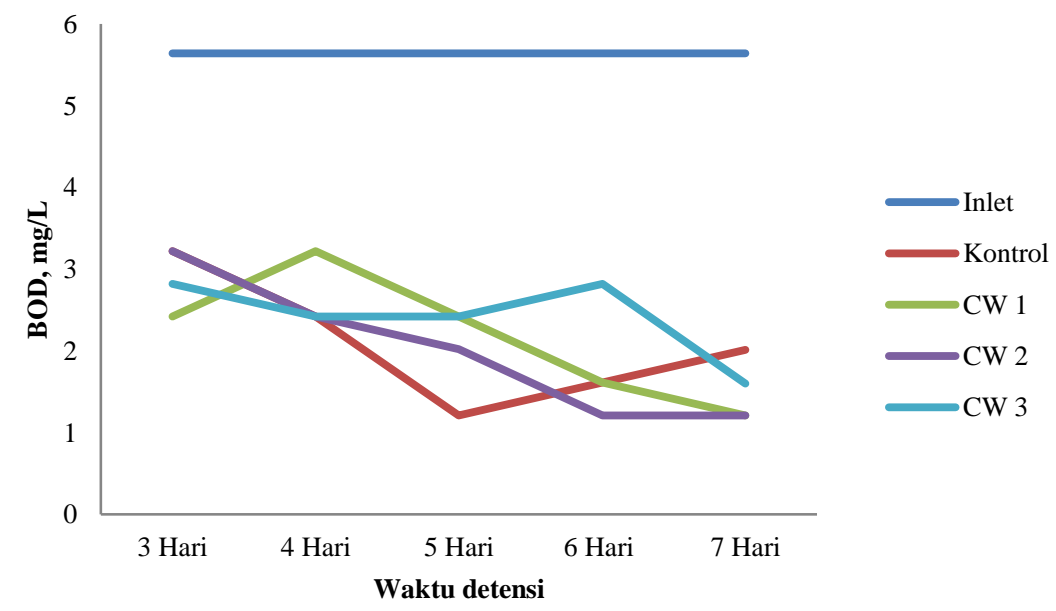

Gambar 2. Pengaruh waktu detensi dan kondisi reaktor terhadap konsentrasi BOD

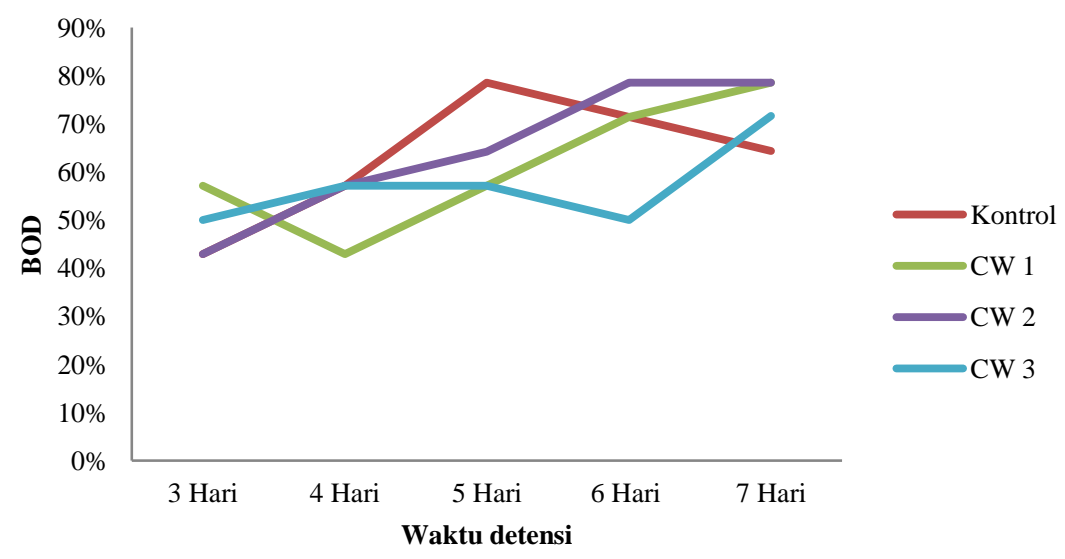

Gambar 3. Pengaruh waktu detensi dan kondisi reaktor terhadap persentase reduksi BOD

\subsection{Pengaruh Waktu Detensi dan Kondisi Reaktor Constructed Wetlands Terhadap Parameter TSS}

Konsentrasi TSS grey water sebelum pengolahan berada di bawah baku mutu limbah domestik. Setelah mengalami pengolahan nilai TSS mengalami penurunan dan berada di bawah baku mutu Permen LH no.5 tahun 2014 (KemenLH, 2014), sebagaimana yang diilustrasikan pada gambar 4. Konsentrasi TSS cenderung mengalami penurunan dengan bertambahnya waktu detensi, dimana efluen terendah dicapai pada waktu detensi 7 hari untuk semua reaktor. Konsentrasi TSS efluen terendah terdapat pada reaktor CW3 dengan jumlah batang dan daun melati air terbanyak. Penurunan kandungan TSS setelah proses pengolahan dengan menggunakan melati air disebabkan karena lapisan media filter tanaman (batuan pecah dan tanah), terjadi proses penyerapan oleh tanaman, dekomposisi bahan organik terlarut dan mengendapnya hasil dekomposisi bahan organik (Fachrurozi dkk., 2010 dalam Wirawan, W. A., Wirosoedarmo, R., Susanawati, L. D., 2013; Kivaisi 2001; Vymazal, J., 2010). Akar serabut tanaman melati air diduga juga berpengaruh pada penurunan TSS. Bentuk serabut akar memungkinkan koloid menempel pada akar-akar tersebut. Penurunan TSS berpengaruh pada penurunan konsentrasi BOD (Fachrurozi dkk., 2010 dalam Wirawan, W. A., Wirosoedarmo, R., Susanawati, L. D., 2013; Kivaisi 2001; Vymazal, J., 2010). 


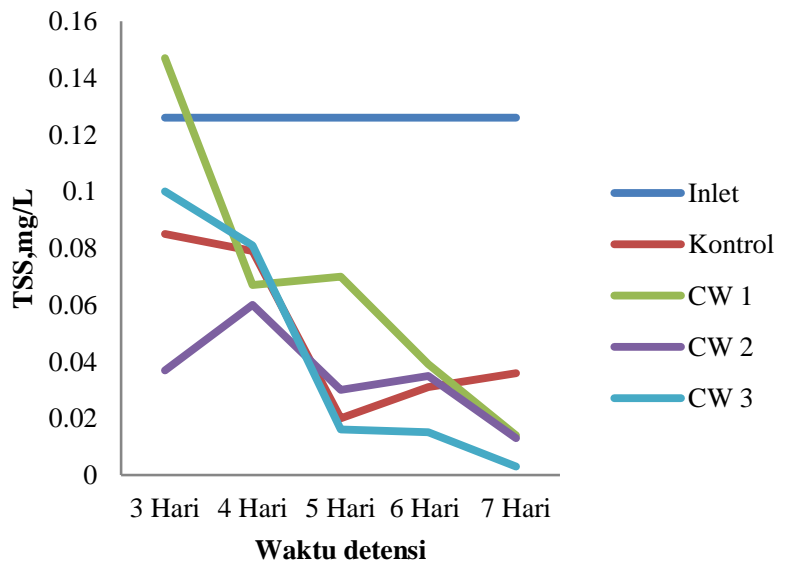

Gambar 4. Pengaruh waktu detensi dan kondisi reaktor terhadap konsentrasi TSS

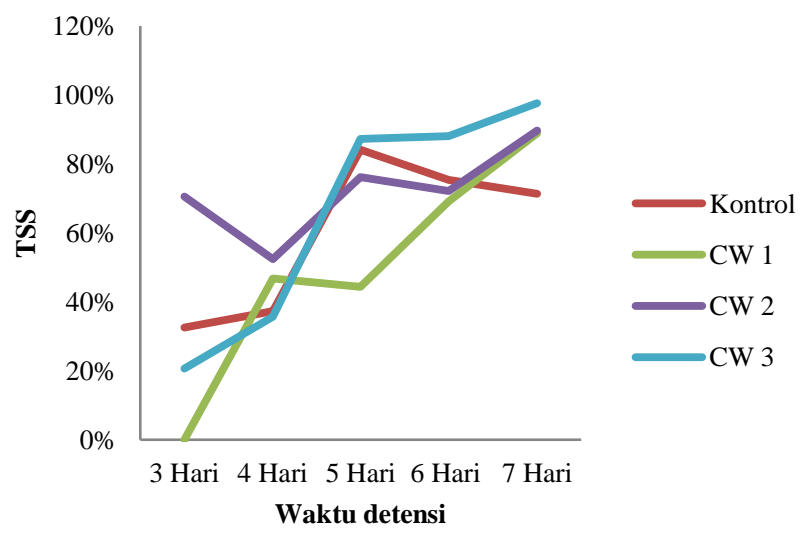

Gambar 5. Pengaruh waktu detensi dan kondisi reaktor terhadap reduksi BOD

\section{Kesimpulan}

Hasil dari penelitian menunjukkan bahwa waktu detensi dan kondisi reaktor sangat berpengaruh terhadap penurunan BOD dan TSS. Konsentrasi efluen terlihat fluktuatif, tapi secara umum terjadi penurunan konsentrasi BOD dan TSS. Konsentrasi efluen BOD dan TSS menurun dengan bertambahnya waktu detensi. Adapun berdasarkan kondisi reaktor tanaman, disimpulkan makin banyak jumlah daun, makin banyak batang tanaman, makin banyak akar tanaman maka makin rendah efluen BOD dan TSS. Konsentrasi BOD dan TSS secara berurut berkisar $(1,6-3,22) \mathrm{mg} / \mathrm{L})$ dan $(0,003-0,147) \mathrm{mg} / \mathrm{L}$.

\section{Ucapan Terima Kasih}

Penulis mengucapkan apresiasi dan terima kasih pada Lembaga Penelitian dan Pengabdian Pada Masyarakat (LPPM) Universitas Batanghari yang telah mendanai penelitian ini melalui skim penelitian kompetitif dana rutin Universitas Batanghari Tahun Anggaran 2017 dengan Kontrak Surat Perjanjian Pelaksanaan Penelitian Nomor: 01/UBR - LPPM/2017.

\section{Daftar Pustaka}

Eriksson, E., Auffarth, K., Henze, M., \& Ledin, A. (2002). Characteristics Of Grey Wastewater, Urban Water 4, 85-104.

Handayani, S.D. (2013). Kajian Pustaka Potensi Pemanfaatan Greywater Sebagai Air Siram WC dan Air Siram Tanaman di Rumah Tangga. Jurnal PRESIPITASI 10 (1), $41-50$.

Kasman, M., Ibrahim, S., Salmariza. (2012). Removal of Iron from Aqueous Solution by Rice Husk: Isotherm and Kinetic Study. Jurnal Litbang Industri, 2(2), 63-70.

Kasman, M., Kalsum, S.U., Aditia, A.S., (2012). Reduksi pH, BOD dan COD dalam Grey Water dengan Proses Elektrokuagulasi-Sedimentasi Jurnal Ilmiah Universitas Batanghari Jambi 12(3), 2-5.

KemenLH, 2014. Peraturan Menteri Lingkungan Hidup Republik Indonesia Nomor 5 Tahun 2014 Tentang Baku Mutu Air Limbah. Jakarta.

Kivaisi, A. K. (2001). The Potential for Constructed Wetlands for Wastewater Treatment and Reuse In Developing Countries: A Review. Ecological Engineering 16, 545 $-560$

Prayitno, 2013. Pengurangan BOD dan COD Limbah Cair Terolah Industri Penyamakan Kulit Menggunakan Tanaman Melati Air. Majalah Kulit, Karet dan Plastik 29 (1), 27 - 42.

Suprihatin, H. (2014). Penurunan Konsentrasi BOD Limbah Domestik Menggunakan Sistem Wetland dengan Tanaman Hias Bintang Air (Cyperus alternifolius). Dinamika Lingkungan Indonesia, 80 - 87.

Suswati, A.C.S.P., Wibisono, G. (2013). Pengolahan Limbah Domestik Dengan Teknologi Taman Tanaman Air (Constructed Wetlands). Indonesian Green Technology Journal 2 (2), 70-77.

Vymazal, J. (2002). The use of sub-surface constructed wetlands for wastewater treatment in the Czech Republic : 10 years experience. Ecological Engineering $18,633-646$.

Vymazal, J. (2008). Plant Dynamics and Management in Constructed and Natural Wetlands. Netherlands: Springer: Dordrecht, The Netherlands.

Vymazal, J. (2010). Constructed Wetlands for Wastewater Treatment: A Review. Water 2, 530-549, http://doi.org/10.3390/w2030530.

Wirawan, W. A., Wirosoedarmo, R., Susanawati, L. D. (2013). Pengolahan Limbah Cair Domestik Menggunakan tanaman Kayu Apu (Pistia Stratiotes L.) Dengan Teknik Tanam Hidroponik Sistem Dft (Deep flow technique). Jurnal Sumberdaya Alam dan Lingkungan, 63 - 70. 